\title{
RAZVOJ SHVAĆANJA „JAVNOSTI“ ORGANIZACIJA U ORGANIZACIJSKOJ TEORIJI
}

Dr. sc. Mariza Menger*

\author{
UDK $352 / 353$ \\ https://doi.org/10.30925/zpfsr.39.2.10 \\ Ur.: 15. svibnja 2017. \\ Pr.: 14. ožujka 2018. \\ Pregledni znanstveni rad
}

\begin{abstract}
Sažetak
U radu se razmatra kako se u okviru teorije organizacije konceptualiziraju pojmovi javnog i privatnog. Cilj je rada pokazati kako se s upravnim razvojem mijenjaju $i$ pristupi razlikovanju javnih i privatnih organizacija. Uprava se razvija u smjeru sve većeg približavanja javnog i privatnog sektora. Taj je razvoj uvjetovao i redefiniranje pojmova javne i privatne organizacije. Tradicionalno javne organizacije bile su definirane kao javne, a privatne kao privatne, prema formalnom, pravnom kriteriju vlasništva: organizacije u vlasništvu države smatrane su javnima, organizacije u vlasništvu privatnog aktera, privatnima. Suvremeni razvoj uprave doveo je u pitanje ovu formulu, stoga se danas mogu identificirati četiri pristupa u definiranju ,javnosti“ organizacije: najstariji formalni, zatim dimenzionalni, normativni i integrativni.
\end{abstract}

Ključne riječi: teorija organizacije, javne službe, javna uprava, javni sektor, novi javni menadžment.

\section{UVOD}

Suvremeno društvo obilježava brisanje (ili barem zamagljivanje) granice između javnog i privatnog sektora. Redefiniranje granica države i tržišta na način da se oni sve više prožimaju i isprepleću jednim je dijelom posljedica reformi druge polovice 20. stoljeća. Iako su prvotno bile zamišljene i usmjerene na smanjenje javne uprave i širenje prostora djelovanja tržišta prepuštajući mu niz djelatnosti nekada rezerviranih za organizacije državne uprave (poput mrežnih industrija, vodoopskrbe, zdravstva i druge), posljedica menadžerskih reformi bila je formiranje javnog sektora, prostora zajedničkog djelovanja javnog i privatnog. U kontekstu javnih službi, primjerice, u njihovu obavljanju ne sudjeluju više isključivo javna poduzeća i javne ustanove, već su sve češći različiti oblici suradnje javne uprave i privatnih aktera. Kako bi se ovi novonastali oblici opisali, iskonstruirano je niz novih pojmova: javno-privatno partnerstvo, contracting out (vanjsko ugovaranje), outsourcing i drugi. Odnosno, u praksi se pojavila situacija da se „služenje“ javnom interesu očekuje od sve većeg

* Dr. sc. Mariza Menger, asistentica Sveučilišta u Rijeci, Pravnog fakulteta; mmenger@pravri.hr. 
broja organizacija koje izvorno nisu dio državnog upravnog aparata ili javne uprave. S druge strane, jasnu distinkciju između javne i privatne sfere dovode u pitanje i drugi procesi karakteristični za suvremeni upravni razvoj, primjerice, proces agencifikacije javne uprave. Radi se o širenju posebnog tipa upravne organizacije, agencije, koja, iako je dio državne uprave, uživa posebnu autonomiju u odnosu spram institucija političke vlasti. Konačno, moderne upravne organizacije u više ili manje prihvaćaju menadžerske tehnike iz privatnog sektora, kao što je fleksibilizacija radnog odnosa službenika i napuštanje tradicionalnog karijernoga sustava.

Velik je broj autora skeptičan pred ovakvim upravnim razvojem i sve češće upozorava na negativne učinke reformi. Moran, primjerice, ukazuje na katastrofalne posljedice privatizacije vodoopskrbe i željeznice u Velikoj Britaniji, inače jednoj od država predvodnica reformi. Wollmann i Marcou te Kuhlmann navode problematične posljedice menadžerski orijentiranih reformi na lokalnoj razini u Njemačkoj i Francuskoj. Posljedica reformi u tim državama bila je ne samo povećanje cijene lokalnih službi, već i fragmentacija lokalnih institucija, smanjenje upravljačkog kapaciteta lokalnih vlasti kao i manji utjecaj građana na lokalno upravljanje. ${ }^{1}$

Cilj ovoga rada, međutim, nije istražiti i upozoriti na moguće negativne posljedice suvremenih upravnih reformi, već uputiti na teorijsku raspravu koja stoji u njihovoj pozadini, o razlici između javnih i privatnih organizacija. Pitanje postoje li uopće bitne razlike između jednih i drugih organizacija nije nevažno, jer će, primjerice, potvrdan odgovor implicirati, u najmanju ruku, oprez pri uključivanju privatnih poduzeća u javne sektore pojedine države. Osnovna je intencija rada pokazati kako „određeni novi pogledi u znanosti o organizaciji odražavaju ne samo napredovanje u mišljenju već podjednako i promjene u stvarnosti.“2 Odnosno, bit je rada prikazati razvoj shvaćanja ,javnog" i ,privatnog“ u teoriji organizacije. Pojava javnog sektora, kao posljedica suvremenih upravnih reformi, utječe na promijenjeno shvaćanje javnog i privatnog. Tradicionalno javne organizacije bile su identificirane kao javne, a privatne kao privatne, prema formalnom, pravnom kriteriju vlasništva: organizacije u vlasništvu države smatrane su javnima, organizacije u vlasništvu privatnog aktera, privatnima. Pojava javnog sektora kao prostora sve većega približavanja javne i privatne sfere dovela je u pitanje ovu formulu. U situaciji kada se sve veći udio stanovnika i razvijenih i zemalja u razvoju oslanja na privatni sektor za zadovoljenje temeljnih životnih potreba (komunalne službe, obrazovanje, čak i zdravstvo) ne začuđuje da se pristup definiranju javnog i privatnog promijenio.

U tom se smislu u radu najprije definiraju pojmovi javne uprave i javnog sektora i upućuje se na noviji razvoj javne uprave. U drugom dijelu daje se kratki pregled organizacijskog pristupa u upravnoj znanosti, a u zadnjem se dijelu prikazuje kako se u okviru organizacijske teorije razvijalo i mijenjalo shvaćanje ,javnosti“.

1 Kuhlmann, S., Reforming Local Public Services: Trends and Effects in Germany and France, Public Management Review, vol. 10, 5/2008., str. 581 i d.; Wollmann, H., Marcou, G., From Public Sector-based to Privatized Service Provision. Is the Pendulum Swinging Back Again? Comparative Summary, u: Wollmann, H., Marcou, G. (ur.) The Provision of Public Services in Europe, Between State, Local Government and Market, Edward Elgar, Cheltenham/ Northampton, 2010., str. 255-256.

2 Pusić, E., Upravljanje u suvremenoj državi, Zagreb, Suvremena javna uprava, 2002., str. 15. 


\section{SUVREMENI UPRAVNI RAZVOJ}

Javna uprava, odnosno skup upravnih organizacija koji u okviru neke političke zajednice obavlja javne poslove, u literaturi je uobičajeno prikazan kao sustav koji se sastoji od tri elementa: državne uprave, teritorijalne samouprave i organizacije javnih službi. ${ }^{3}$ Pritom je ovo posljednje, javne službe, glavno područje u kojem se širi uprava u 20. stoljeću. Ono je tradicionalno bilo organizirano kao mreža javnih ustanova (primjerice, škole i prosvjetne ustanove, zdravstvo, socijalna zaštita) i javnih poduzeća (primjerice, komunalna poduzeća). U zadnjoj četvrtini 20. stoljeća, međutim, kao odgovor na, tzv. krizu socijalne države, javne uprave zemalja OECD-a, ali i zemalja u razvoju i tranzicijskih zemalja, prolaze kroz značajne reforme. Te su promjene obuhvaćene nazivom novi javni menadžment (dalje: NJM). Radi se o upravno-tehničkoj doktrini prema kojoj upravljanje u državnoj, odnosno javnoj upravi nije posebne naravi te se stoga treba inspirirati tržišnim metodama i načinom upravljanja. ${ }^{4}$ Pritom je korisno je pritom razlikovanje dva aspekta NJM reformi: vanjskog (eksternog) i unutarnjeg (internog). Vanjski aspekt reformi odnosi se na strukturalne promjene. Odnosno, na novu redistribuciju poslova između države i tržišta, privatnog i javnog sektora, favorizirajući pritom ovo posljednje. Ova redistribucija poslova očituje se u različitim vidovima sudjelovanja privatnog sektora, privatnih poduzeća, u obavljanju javnih službi. Interni aspekt reformi odnosi se na promjene u metodama i tehnikama upravljanja, primjerice, promjene u sustavu upravljanja ljudskim potencijalima (uvođenje vremenski ograničenih ugovora za javne službenike, nagrađivanje prema izvršenju i sl.) ili pojava niza novih instrumenata upravljanja kvalitetom u upravnim organizacijama (ispitivanje zadovoljstva korisnika, ISO standardi kvalitete, povelje građana, nagrade za kvalitetu u javnom sektoru i sl.). ${ }^{5}$

Navedene su reforme za posljedicu imale privatizaciju čitavog niza djelatnosti, osim onih za koje se smatralo da su od posebnog interesa za državu i da zahtijevaju njezinu odgovornost. U Velikoj Britaniji su, primjerice, 1982. privatizirane naftna

3 Koprić, I. i dr., Upravna znanost. Javna uprava u suvremenom europskom kontekstu, Zagreb, Pravni fakultet Sveučilišta u Zagrebu, 2014., str. 3.

4 NJM reforme utemeljene su na neoliberalnoj ideologiji koja je uzela maha tijekom osamdesetih godina zahvaljujući, tzv. čikaškoj školi ekonomista na čelu s nobelovcem Miltonom Friedmanom. Predstavnici Škole zastupaju stajalište da se čovjek ponaša ekonomski racionalno (homo oeconomicus) težeći za ostvarenjem vlastitih ciljeva. Polazeći od te teze nastoje dokazati da slobodno djelovanje tržišta potpune konkurencije maksimira opće blagostanje. Svaka intervencija države u ekonomski život smanjuje blagostanje. Stoga zagovaraju isključivanje države iz ekonomske sfere. Friedman je pobornik laissez-fairea, odnosno Smithove nevidljive ruke. Slobodno tržišno kapitalističko društvo ,jača slobodu“. A ona, pak, predstavlja ključnu vrijednost kojoj su sve ostale vrijednosti poput pravednosti, solidarnosti ili jednakosti podređene. Freidmanove stožerne ideje su deregulacija, kresanje javne potrošnje i privatizacija. Perko-Šeparović, I., Izazovi javnog menadžmenta - dileme javne uprave, Zagreb, Golden marketing - Tehnička knjiga, 2006., str. 75; Blažević, R., Upravna znanost, Rijeka, Pravni fakultet Sveučilišta u Rijeci, 2016., str. 382; Mikić, M. i dr. (ur.), Ekonomski leksikon, 2. izd., Zagreb, Leksikografski zavod Miroslav Krleža/Masmedia, 2011., str. 96.

5 Kuhlmann, S., op. cit., str. 574.; Koprić, I., Kriza socijalne države i menadžerske reforme javne uprave, u: Koprić, I. (ur.) Javna uprava. Nastavni materijali, Zagreb, Društveno veleučilište u Zagrebu/Pravni fakultet u Zagrebu, 2006., str. 149-158. 
industrija i cestovni promet, 1984. telekomunikacije, 1986. plin i brodogradnja, 1987. zračne luke i zračne vlasti, 1988. industrija čelika, 1989. vode, 1991. elektroprivreda, 1994. ugljenokopi, od 1994. do 1995. željeznice. ${ }^{6}$ Time su nestali državni monopoli na brojnim područjima, tradicionalno pod ingerencijom države i u sklopu sustava javnih službi, a uvedeno je tržišno natjecanje. ${ }^{7}$

Reforme NJM-a za posljedicu imaju transformaciju javne uprave. Sve se češće govori o javnom sektoru. Njega obilježava postojanje, tzv. paradržavnih organizacija. Prema Pusiću, radi se o dvije vrste organizacija. Prva skupina paradržavnih organizacija državnog je podrijetla. To su organizacije koje je stvorila država, a preko njih ostvarila neke svoje ciljeve za koje organi državne uprave, iz bilo kojeg razloga nisu podesno oruđe. Tu, primjerice, ulaze organizacije za obavljanje obavještajnih poslova, poslova trgovine oružjem, financiranje političkih stranaka, subvencioniranje novina, regulaciju određenih područja gospodarstva ili zajedničke gospodarske inicijative preko državno-privatnih tijela, autonomna privredna poduzeća koja je osnovala država, ali ih u njihovoj djelatnosti ne želi podvrći političkoj kontroli i utjecaju. ${ }^{8}$ Neke od tih organizacije ulazile bi i u kategoriju agencija. ${ }^{9}$

Druga skupina paradržavnih organizacija nedržavnog je podrijetla koje su po svojoj djelatnosti od početka bile ili su s vremenom dospjele u krug javnih interesa. U drugoj skupini nalaze se privatna poduzeća koja svojom proizvodnjom zadiru u javni interes, kao što su tvornice oružja, privatne organizacije za socijalnu zaštitu ili zdravstveno osiguranje, organizacije za regulaciju sportskih natjecanja, privatne škole i privatne zdravstvene ustanove. U ovu bi skupinu ulazio i sve veći broj međunarodnih organizacija nedržavnog karaktera, kao što su međunarodne znanstvene i sveučilišne ustanove, međudržavne banke, investicijska udruženja i druge slične organizacije. ${ }^{10}$

Javni je sektor stoga područje koje obuhvaća organe i organizacije državne uprave, ali ne samo njih, već i niz drugih organizacija koje obavljaju javne poslove bez stabilne međusobne podjele dužnosti i ovlasti, a nalaze se pod posebnim režimom

6 Perko-Šeparović, I., op. cit., str. 86.

7 Izravne posljedice privatizacija britanskih željeznica 1996. godine bile su nepouzdana usluga, najviše cijene u Zapadnoj Europi i nagomilani dugovi koji su premašivali one starog nacionaliziranog poduzeća. Štoviše, poduzeća koja su se bavila prijevozom putnika kao i poduzeće koje je osnovano za upravljanje sustavom (Railtrack) našli su se korak do bankrota. Sustav je bio zaduženiji nego ikada prije, sigurnost prometa je stalno opadala, a državna potpora je u stvari bila veća nego prije privatizacije. Uz to, ugašen je i jedinstveni centralizirani sustav usavršavanja radnika koji je naglasak stavljao na sigurnost prometa. Cijeli fijasko privatizacije izašao je na vidjelo 2000. godine kada je u tragičnom sudaru vlakova kod Hatfielda život izgubilo nekoliko osoba. Moran, M., Not Steering but Drowning: Policy Catastrophes and the Regulatory State, The Political Science Quarterly, vol. 72, 4/2001., str. 419.

8 Pusić, E., Modernizacija uprave - obrati i trajanja, u: Pusić, E. (ur.) Upravna znanost, Zagreb, Naklada Naprijed, 1995., str. 34.

9 Ministarstvo i agencija dva su suprotna organizacijska oblika za obavljanje javnih poslova. Ministarstva su multifunkcionalne, velike organizacije, koje integriraju oblikovanje javnih politika, regulaciju i implementaciju, podvrgnute hijerarhijskoj kontroli i političkom vodstvu, agencije su specijalizirane, manje organizacije, usmjerene na implementaciju uz kontrolu rezultata i učinaka i sa stručnim vodstvom. Koprić, I. i dr., op. cit., str. 200.

Pusić, E., Modernizacija..., cit., str. 34. 
pravne regulacije i javnog financiranja. ${ }^{11}$,Zajedničke su karakteristike javne uprave i ostatka javnog sektora djelovanje u javnom interesu, obavljanje javnih poslova te opći politički i javni nadzor nad njima. No dok su organizacije javne uprave regulirane javnim pravom, druge organizacije koje pripadaju u javni sektor u velikoj su mjeri podložne pravnom režimu privatnog prava. To se posebno odnosi na njihovo organiziranje, obavljanje djelatnosti i radnopravni status zaposlenika."12

Tradicionalna javna uprava strogo je hijerarhijski sustav. Hijerarhija odnosa vrijedi i unutar pojedine upravne organizacije u sustavu tomu između organizacija koje čine upravni sustav neke političke zajednice. Nasuprot toga, struktura javnog sektora nije jedinstvena. Mjestimično vlada hijerarhija unutar organizacija javnog sektora kao i između njih, a mjestimično međusobni odnosi imaju obilježja mreže. ${ }^{13}$ „Umjesto relativno čvrstog i transparentnog sustava javne uprave u suvremeno se vrijeme suočavamo sa širokim i nepreglednim javnim sektorom. Unutar njega postoje dijelovi koji nesumnjivo imaju obilježje sustava (državna uprava, lokalna samouprava, javne službe). No, uz tu jezgru on u svojim širokim rubnim dijelovima obuhvaća i čitav niz drugih subjekata koji su s jezgrom povezani tek relativno labavim financijskim, usmjeravajućim, pravnim, nadzornim ili sličnim vezama. ${ }^{\text {"14 }}$

Odnos građana prema upravi također se transformira. Građani se prema organizacijama javnog sektora pojavljuju u nizu specijalnih uloga: kao birači, proizvođači, potrošači, korisnici, pacijenti, klijenti itd. Svaka od tih uloga specifično je uređena i u okviru svake građani raspolažu posebnim zakonskim sredstvima ostvarivanja odnosno obrane svojih interesa. ${ }^{15}$ Prema Kopriću, upravo je položaj građana najproblematičniji aspekt javnog sektora. Javni je sektor zamršen, netransparentan, kompliciran, promjenjiv, nestalan i teško predvidljiv pa se građani u njemu teško snalaze, nemaju dovoljno informacija i pregled nad situacijom. Stoga je potrebno ostvariti nove pretpostavke za osiguranje participacije građana. To znači, primjerice, inzistirati na otvorenosti i javnosti rada uprave, težiti informacijskoj ravnoteži između građana i uprave, osigurati političku nezavisnosti medija s obzirom na to da oni uvelike oblikuju javno mnijenje te osiguravati senzibilnost javne uprave za inicijative, želje, interese i prijedloge građana. ${ }^{16}$

U svakom slučaju, u posljednjoj četvrtini 20. stoljeća država gubi onaj značaj koji je ranije imala. „Država postaje sve više samo jedna od domena i u obavljanju onih poslova koji su se tradicionalno smatrali državnim djelokrugom. "17 Unatoč brojnim kritikama, tekovine menadžerskih reformi nisu bitno dovedene u pitanje. Novije upravne doktrine, kao što je dobra uprava (engl. good governance) ili doktrina neoweberijanske uprave, nastoje samo ublažiti disfunkcionalne posljedice NJM-a. ${ }^{18}$

11 Loc. cit.

12 Koprić, I. i dr., op. cit., str. 4.

13 Pusić, E., Modernizacija..., cit., str. 36.

14 Koprić, I., Građani i uprava, u: Koprić, I. (ur.) Javna uprava. Nastavni materijali, Zagreb, Društveno veleučilište u Zagrebu/Pravni fakultet u Zagrebu, 2006., str. 23.

15 Pusić, E., Modernizacija..., cit., str. 36-37.

16 Koprić, I., Građani..., cit., str. 23.

17 Pusić, E., Modernizacija..., cit., str. 34.

$18 \mathrm{U}$ tom smislu doktrina dobre uprave nastoje pomiriti zahtjev za efikasnom upravom sa 
Suvremeni upravni sustav stoga najbolje opisuje koncept javnog sektora.

\section{POVIJESNI PREGLED RAZLIČITIH SHVAĆANJAO ORGANIZACIJI}

Uobičajen teorijski pristup u izučavanju javne uprave, odnosno javnog sektora je onaj organizacijski. Teško je, međutim, govoriti o jedinstvenoj teoriji organizacije. Većina se autora slaže da se prije radi o skupu različitih pristupa fenomenu ljudske suradnje koji svoje korijene imaju u više od jedne discipline. Koprić, primjerice, navodi sedam pravaca u izučavanju organizacije: mehanicistički, teorija organizacijskog konflikta i moći, teorija odlučivanja, interesno-politički pravac, teorija otvorenog sustava, kibernetski pravac, teorija samoreferentnih i autopoietskih sustava. ${ }^{19}$ Morgan čak i ne govori o teorijama već različitim metaforama ili slikama organizacije (engl. images) i navodi ih osam: organizacija kao stroj, kao organizam, učeća organizacija ili organizacija kao mozak, organizacija kao politički sustav, organizacija kao psihološki zatvor, organizacija kao tok i transformacija, organizacija kao instrument dominacije. ${ }^{20}$ Prema Pusiću sustavni se pristup izučavanju fenomena organizacije pojavio u 19 . stoljeću u djelima Adama Smitha, Karla Marxa i Maxa Webera, a svoj neizbrisiv pečat dobiva u 20. stoljeću spajajući se s novom teorijom sistema i srodnim matematičkim teorijama kibernetike, informacijskom teorijom i teorijom igara. ${ }^{21}$

Korijeni organizacijskog pristupa u izučavanju uprave su dvostruki. On se nastavlja i na radove autora koji su u izučavanju fenomena organizacije pred očima imali organizacije privatnog sektora, privatna poduzeća i na radove autora koji su bili usmjereni na upravne organizacije. Pojava znanosti o organizaciji i upravljanju kao nove samostalne discipline vezana je uz ubrzani proces industrijalizacije na prijelazu u 20. stoljeće. Industrija je počela upošljavati velike mase u pravilu neiskusnih radnika. Oni su u radu često upotrebljavali oruđe koje su sami donijeli u tvornicu, a ako su radili na strojevima, sami su određivali brzinu stroja po svom nahođenju. Učenje je bilo prepušteno slučaju i uglavnom se svodilo na promatranje iskusnijih radnika. Predradnici su u svojim rukama imali veliku moć. Odlučivali su o zapošljavanju novih

zahtjevom za demokratskom upravom inzistirajući na odgovornosti i transparentnosti uprave i građanskoj participaciji. Pojam neo weberijanske javne uprave u literaturu je uveden kako bi se opisalo ishode menadžerski orijentiranih reformi u kontinentalno-europskim zemljama. Naime, za razliku od anglosaksonskih zemalja (SAD-a, Velike Britanije, Australije, Novog Zelanda), države europskog kontinenta opreznije su pristupile uvođenju tržišnih metoda i tehnika u svoje javne uprave. Stoga je ishod reformi na područjima sa snažnom legalistički orijentiranom organizacijskom kulturom bio hibridni sustav koji spaja tradicionalne vrijednosti javne uprave, ponajprije poštovanje stroge vezanosti uprave pravnim normama i nove menadžerske vrijednosti i tehnike. Pollit, C., Bouckaert, G., Public Management Reform: A Comparative Analysis - New Public Management, Governance, and the Neo-Weberian State, Oxford, Oxford University Press, 2011., str. 124.

19 Koprić, I., Struktura i komuniciranje u upravnim organizacijama, Zagreb, Pravni fakultet Sveučilišta u Zagrebu, 1999., str. 8-32.

20 Morgan, G., Images of Organization, Thousand Oaks/London/New Delhi, SAGE Publications, 1997.

21 Pusić, E., Upravljanje..., cit., str. 62-26. 
radnika, o otkazu i odmoru. Arbitrarno odlučivanje bilo je uobičajeno. Na najnižoj, operativnoj razini posao se ne samo obavljao, već i koordinirao. Akcija i razmišljanje o njoj bili su spojeni. ${ }^{22}$ Stoga, ne čudi kako prve ideje o organizaciji dolaze iz prakse i namijenjene su praksi. U tom smislu u literaturi se najčešće navode imena dvojice autora, Amerikanca Frederica Winslowa Taylora i Francuza Henrya Fayola. Ono što je zajedničko u njihovom pristupu organizaciji, a koji se još naziva i mehanicistički, je potraga za metodama povećanja produktivnosti rada, a onda i povećanje učinkovitosti organizacije u ostvarenju određenoga cilja, profita.

Taylor je ponajprije bio zainteresiran za racionalizaciju fizičkih radnih operacija u industriji. Svaka radna operacija može se analizom njezina sadržaja i mjerenjem trajanja pojedinih pokreta od kojih se sastoji, učiniti djelotvornijom i ekonomičnijom. Samo je jedan najbolji put u obavljanju svakog posla. Rezultat je njegova pristupa opća standardizacija radnika, metoda, vremena, kvantitete i kvalitete rada kao i radne okoline. Radi se o znanstvenom upravljanju (engl. scientific management), ideji kako je znanstvenom metodom, koja je objektivna, moguće doći do utvrđivanja ,poštenog dnevnog rada“ i za nju vezane odgovarajuće dnevne zarade radnika. ${ }^{23}$

Fayol je, pak, problemu učinkovitosti organizacije pristupio s više razine upravljanja, rukovođenja. Djelokrug vrhovnog rukovoditelja činile bi sljedeće djelatnosti: predviđanje, organiziranje, zapovijedanje, koordinacija i nadzor. Dok je kod Taylora težište na diobi rada, na krajnjoj racionalizaciji konačnih rezultata procesa diobe pojedinih fizičkih radnih operacija, Fayol se zanima za proces integracije, kako najbolje povezati brojne i mnogovrsne radne operacije i usmjeriti čitavu djelatnost prema cilju ili ciljevima organizacije kao cjeline. ${ }^{24}$

Max Weber organizaciju kojom se bavi naziva birokratsko-monokratskom ili jednostavno „,birokracijom“. Iako Weber ovaj tip organizacije primjenjuje podjednako i na javnu upravu i na organizacije privatne sfere (privatna poduzeća), njegova terminologija i način razmišljanja potječu ponajprije iz sfere državne uprave. ${ }^{25}$ Karakteristike ovog tipa organizacije su: ljudi su osobno slobodni i podvrgnuti su vlasti samo u odnosu na svoje neosobne službene dužnosti; organizacija službi osniva se na hijerarhijskom načelu; dužnosti su jasno određene; služba se popunjava na osnovi slobodnog ugovornog odnosa u legalnom smislu, pa u načelu postoji slobodan izbor; kandidati se biraju na osnovi tehničkih kvalifikacija, provjerenih ispitima i/ili

22 Perko-Šeparović, I., Teorije organizacije, Zagreb, Školska knjiga, 1975., str. 9-10.

23 Ibid., str. 11-12.

24 Prvi kritičari Taylora i Fayola bili su pripadnici škole međuljudskih odnosa ili tzv. humanisti. Istaknuto mjesto među njima ima Elton Mayo. Oni su smatrali kako se ljudsko ponašanje u organizaciji ne može objasniti isključivo s ekonomskog aspekta. Ono je često rezultat emocija pa ne mora biti racionalno. Pokazali su da socijalne potrebe za ljubavlju i pripadanjem motiviraju pojedinca na uključivanje $u$ razne neformalne organizacijske skupine čije vrijednosti i norme postaju glavni kriterij njihova ponašanja. Ipak i njima je u cilju bilo povećanje produktivnosti u privrednom poduzeću. Za razliku od mehanicističkog modela organizacije, koji se temelji na stajalištu da iz najveće efikasnosti organizacije proizlazi najveće zadovoljstvo zaposlenika, škola međuljudskih odnosa počiva na ideji da najveće zadovoljstvo zaposlenika rađa povećanu efikasnost. Marčetić, G., Upravljanje ljudskim potencijalima u javnoj upravi, Zagreb, Društveno veleučilište u Zagrebu, 2007., str. 76.

25 Pusić, E., Upravljanje..., cit., str. 6. 
diplomama; oni su imenovani, a ne izabrani; u pravilu se plaćaju u novcu i imaju pravo na mirovinu; služba je jedino ili bar osnovno zanimanje; služba je karijera jer postoji sustav napredovanja prema dužini staža i/ili uspjehu; u svojem djelovanju potpuno su odvojeni od materijalnih sredstava upravljanja i ne mogu prisvojiti svoj položaj; podvrgnuti su sistematskoj disciplini i kontroli u ponašanju u službi. ${ }^{26}$ Takav model upravne organizacije, koja počiva na propisanim pravilima i stručnom znanju javnih službenika, do danas nije izgubio na važnosti. Njegova deskriptivna obilježja postaju preskriptivna načela kojima bi demokratska državna uprava trebala težiti. ${ }^{27}$ Fayol, Taylor i Weber, kao i njihovi sljedbenici i eventualni kritičari, koji su djelovali u prvoj polovici 20. stoljeća poput Eltona Mayoa, Mary Parker Follet, Luthera Gulicka, Chestera Bernarda i drugih, pripadnici su tzv. klasične škole organizacije. ${ }^{28}$

Sredinom 20. stoljeća u teoretskom promišljanju o organizaciji osobito se korisnim pokazao sistemski pristup. Njegovim rodonačelnikom smatra se Ludwig von Bertalanffy, koji je nastojao istražiti mogućnost teorijskog jedinstva svih znanstvenih disciplina i društvenih i prirodnih. Njegove se ideje temelje na opservaciji kako se društvo sastoji od manjih grupa, grupe od pojedinaca, pojedinci od organa, organi od stanica, stanice od molekula, molekule od atoma i tako dalje. Svaki od tih fenomena Bertalanffy je smatrao sistemom i vjerovao kako postoje zakonitosti koje su im svima zajedničke. ${ }^{29}$ Cilj je opće teorije sistema pronalaženje i formulacija načela, izomorfnih zakona, koja općenito vrijede za sve sisteme bez obzira na prirodu njihovih elemenata i narav „sile“ koja ih drži na okupu. ${ }^{30}$ Zahvaljujući korištenju apstraktnih pojmova poput „dio“, „cjelina“, „veza“ ili „granica“, pristup je naišao na plodno tlo među teoretičarima organizacije. U organizaciji, bilo u privredi, bilo u upravi, „dio“ je radno mjesto, „veza“ između dijelova je hijerarhijski odnos podređenosti i nadređenosti, a „cjelina“ organizacija s točno određenim granicama definiranim brojem radnih mjesta. $^{31}$

Također, sistemski je pristup omogućio promatranje organizacije kao otvorenog sustava koji se nalazi u stalnom odnosu razmjene s okolinom. Okolina postaje sve češća varijabla $u$ istraživanju fenomena organizacije. $U$ tom pogledu značajna je teorija kontingencije Lawrenca i Lorscha. Oni su uspoređivali više i manje uspješne organizacije u tri različite industrije: prehrambenoj, industriji plastike i kontejnerskoj industriji. Rezultati njihova istraživanja ukazuju na to kako su organizacijske varijable, poput stupnja diferencijacije, načina postizanja integracije i način rješavanja sukoba unutar organizacije, u odnosu s eksternim varijablama, poput izvjesnosti i raznovrsnosti okoline. Odnosno, razlike u „unutrašnjim stanjima“ organizacije kao i procesima

26 Perko-Šeparović, I., Teorije..., cit., str. 21.

27 Marčetić, G., op. cit., str. 49.

28 Shafritz, J. M., Ott, J. S., Jang, Y. S., Classics of Organization Theory, 6. izd., Belmont (SAD), Thomson Wadsworth, 2005., str. 27-33.

29 Hatch, M. J., Cunliffe, A. L., Organization Theory: Modern, Symbolic, and Postmodern Perspectives, 3. izd., Oxford, Oxford University Press, 2013., str. 29.

30 Bertalanffy, L. von, General System Theory - Foundations, Development, Applications, Harmondsworth, Penguin Books, 1973., str. 36.

31 Pusić, E., Modernizacija..., cit., str. 64. 
unutar organizacije mogu se razumjeti na temelju razlika njihovih vanjskih okolina. ${ }^{32}$ Praktično je to značilo da ne postoji „najbolji“ način organiziranja i upravljanja, kako su to tvrdili predstavnici klasične škole organizacije. „Što je najbolje, ovisi od okolnosti mjesta i vremena i ne može se uopće utvrditi na opće obvezatni način. “"33

Informatička revolucija pedesetih i šezdesetih godina 20. stoljeća, u smislu automatizacije, robotizacije i kompjutorizacije rada, ostavlja trag i na teorijskom promišljanju organizacija. Postaje aktualna kibernetička analiza odnosa organizacije i okoline, koja na prvo mjesto stavlja informacije i komunikaciju u organizaciji. ${ }^{34}$ Pojam „kibernetika“ pripisuje se američkom matematičaru Norberu Wieneru, a radi se o metaforičkoj primjeni grčke riječi kubernetes koja je izvorno označavala upravljanje brodom (kormilarenje, navigiranje). Wiener je sliku kormilarenja brodom uzeo kako bi objasnio proces razmjene informacija zahvaljujući kojemu sistemi (organizacije) modificiraju svoje ponašanje (samoregulacija) radi održavanja homeostaze. Osnovni je doprinos teorije mehanizam povratnog djelovanja (engl. negative feed-back). Povratno djelovanje sistema moguće je zahvaljujući kružnom tijeku informacija, stalnoj komunikaciji između sistema i okoline. Poput kormilara koji, na temelju trenutačnog položaja broda, procjenjuje treba li brod nagnuti lijevo ili desno kako se ne bi potopio, odnosno kako bi zadržao optimalni smjer kretanja, svaki sistem, djelujući u okolini, istodobno prima informacije iz okoline o učincima svojih aktivnosti te donosi odluku o potrebnim korekturama svojega ponašanja kako bi osigurao relativno stabilno stanje sustava. ${ }^{35}$

Osamdesetih godina 20. stoljeća u izučavanju uprave aktualan postaje neoinstitucionalni pristup. U tom pokretu ključno mjesto pripalo je dvojici politologa Jamesu Marchu i Johanu Olsenu. Oni su u poznatom članku „Novi institucionalizam: organizacijski faktori u političkom životu“"(The New Institutionalism: Organizational Factors in Political Life) iz 1983., upućujući na nedosljednosti tada aktualnih pristupa u političkoj znanosti, istaknuli potrebu za reafirmacijom institucionalne analize. ${ }^{36}$

32 Lawrence, P. R., Lorsch, J. W., Visoko uspješne organizacije u tri okoline, u: Pusić, E. (ur.) Upravna znanost, Zagreb, Naklada Naprijed, 1995., str. 259 i d.

33 Pusić, E., Modernizacija..., cit., str. 95.

34 Pusić, E., Upravljanje..., cit., str. 25.

35 Morgan, G., op. cit., str. 84. Prema Perko-Šeparović, kibernetika prerasta iz teorije o informacijama i komunikaciji u opću znanost o reguliranju i samoregulaciji u sistemima. U tom se smislu i ideja o, tzv. regulacijskoj državi temelji na kibernetičkoj slici sistema: uprava u regulacijskoj državi, za razliku od socijalne države, ,ne vesla, već kormilari“ (engl. steering not rowing), postavlja ciljeve i nadzire, a ne pruža neposredno usluge (službe) građanima. PerkoŠeparović, I. Teorije..., cit., str. 39; Jordana, J., Levi-Fauer, D. The Politics of Regulation in the Age of Governance, u: Jordana, J., Levi-Fauer, D. (ur.), The Politics of Regulation. Institutions and Regulatory Reforms for the Age of Governance, Cheltenham, Edward Elgar, 2004., str. 11.

36 March i Olsen u svojoj analizi posežu za tekovinama decizionističkog pravca u teoriji organizacije. Jedan je od glavnih predstavnika tog smjera nobelovac Herbert Simon. Njegov je doprinos političkim, ali i drugim društvenim znanostima ideja o „ograničenoj racionalnosti“. Radi se o kritici klasičnog modela odlučivanja koji se pojavio na području ekonomskih disciplina, a prema kojemu idealno racionalni čovjek donosi odluke na osnovi poznavanja svih mogućih alternativa i njihovih mogućih posljedica, kao i pravila na osnovi kojih rangira alternative radi maksimalnog ostvarenja cilja kojemu teži. Klasični je model odlučivanja pritom pred očima ponajprije imao privrednu organizaciju (poduzeće). On inzistira na tomu 
Prema Pusiću institucije su društvene strukture koje obilježava normativnost. Odnosno, radi se o takvim društvenim strukturama u kojima je interakcija aktera uređena društvenim očekivanjima. Primjerice, sin nasljeđuje oca zahvaljujući instituciji nasljedstva. Prolaznik koji prelazi cestu zahvaćen je institucijama regulacije prometa. Kada netko ukrade tuđu stvar, krši norme institucije vlasništva. Institucija podrazumijeva zahtjev za postupanjem na predviđeni način svima onima koji se nađu ili će se naći u određenoj, reguliranoj, situaciji. Svaka se organizacija može promatrati i kao institucija, jer je interakcija u njoj regulirana očekivanjima od kojih se ne odustaje. Stoga su i upravne organizacije, ministarstva, policijske postaje, poštanski uredi, katastri i dr., institucije - društvene strukture obilježene normativnošću kod kojih je interakcija regulirana načelno ireverzibilnim očekivanjima, te ih kao takve treba i proučavati. Iako ne treba zanemariti ni interes klasične upravne znanosti koji je, ponajprije, bio usmjeren na značajke uprave kao sustava organizacija (na njihove ciljeve, članove, metode rada i odnose s okolinom). Međutim, prednost je institucionalne analize upravnih organizacija oslobođenje od prevelike vezanosti za konkretni upravni sustav. ${ }^{37}$

Institucionalizam nije, međutim jedinstveni pristup. Za Selznicka, koji je predstavnik sociološkog institucionalizma, organizacija je racionalni instrument za ostvarivanje ciljeva i u tom smislu zamjenjiva. Ako je neka nova organizacija podesnija za ostvarivanje određenog cilja od postojeće, aktualna će biti zamijenjena. Institucije, pak, nastoje sebe učiniti nezamjenjivima namećući vlastite vrijednosti kao ispravne i potrebne zajednici u okviru koje egzistiraju. ${ }^{38}$ Radi se o procesu institucionalizacije kojeg Meyer i Rowan opisuju kao izgradnju svojevrsnog mita o potrebnosti, poželjnosti i neophodnosti neke konkretne organizacije iza kojeg se često skriva njezino neučinkovito ili, čak protuzakonito djelovanje. ${ }^{39}$

da organizacija ima svoj cilj, maksimizaciju profita, i da je orijentirana na njegovo ostvarenje. Racionalnost pretpostavlja da se neće poduzeti ni jedna akcija koja bi organizaciju udaljila od tog cilja, kao i to da će se donositelj odluke, suočen s dvije ili više alternativa koje bi imale različite posljedice, opredijeliti za onu koja vodi maksimalnom profitu. Naspram toga, Simon smatra kako je donositelj odluke ograničen u svojim mogućnostima spoznaje. Njegov intelektualni kapacitet i kompleksnost okoline organizacije, tj. broj osoba s kojima komunicira i količina raspoloživih informacija, onemogućuju primjenu klasičnog modela odlučivanja koji pretpostavlja da su poznate sve opcije i njihove posljedice. Stvarno odlučivanje ograničeno je na mali broj mogućnosti. Izbor se, naime, uvijek obavlja sa stajališta ograničenog, približnog i pojednostavljenog modela stvarne situacije. Ako ovu spoznaju primijenimo na odlučivanje u političkom sistemu, postaje vrlo važno proniknuti modele, strukture ili institucije, na temelju kojih politički akteri donose odluke. Perko-Šeparović, I., Teorije..., cit., str. 131-137; March, J., Olsen, J., The New Institutionalism: Organizational Factors in Political Life, American Political Science Review, vol. 78, 3/1983., str. 741; Egeberg, M., How Bureaucratic Structure Matters: An Organizational Perspective, u Peters, G. B., Pierre, J. (ur.) The SAGE Handbook of Public Administration, Thousand Oaks/London/New Delhi, SAGE Publications, 2012., str. 144.

37 Pusić, E., Modernizacija..., cit., str. 78 i d.

38 Hatch, M. J., Cunliffe, A. L., op. cit., str. 36.

39 Meyer, J. W., Rowan, B., Institutionalized Organizations: Formal Structure as Myth and Ceremony, u: Powell, W. W., DiMaggio, P. J. (ur.) The New Institutionalism in Organizational Analysis, Chicago/London, University of Chicago Press, 1991., str. 41 i d. 
Dakle, znanost o organizaciji kao posebna disciplina javlja se na prijelazu iz devetnaestog u dvadeseto stoljeće, a barem je jednim dijelom odgovor na promijenjen način života i rada ljudi zbog ubrzane industrijalizacije. Prve je teoretičare zanimalo na koji način povećati produktivnost industrijskih organizacija, odnosno kako optimalno organizirati zajednički rad ljudi u industriji ili organizacijama državne i javne uprave. Disciplina je od svojih početaka za predmet izučavanja imala i organizacije javnog (upravne organizacije) i organizacija privatnog sektora (industrijska odnosno privatna poduzeća). Pristup je doživio posebni uzlet zahvaljujući općoj teoriji sistema koja je interes istraživača, između ostaloga, usmjerila na okolinu organizacije. Od tada sazrijeva shvaćanje kako je traženje jedinstvenog, optimalnog načina organiziranja uzaludno jer što je najbolje (najučinkovitije) ovisi o okolnostima. Uspješna je ona organizacija koja se uspije prilagoditi svojoj okolini, ili, još bolje, koja uspijeva u svojem interesu manipulirati okolinom. Od osamdesetih godina organizacijska je teorija pod utjecajem institucionalne analize. Pažnja je usmjerena ne više samo prema tehničkoj, prirodnoj i društvenoj okolini organizacije, već i prema njezinoj institucionalnoj okolini koju sačinjavaju simbolički elementi, vjerovanja i norme o tomu što je poželjno i dobro.

\section{4. „JAVNOST“ ORGANIZACIJA JAVNOG SEKTORA}

Rad polazi od ideje kako „određeni novi pogledi u znanosti o organizaciji odražavaju ne samo napredovanje u mišljenju već podjednako i promjene u stvarnosti.“40 $\mathrm{U}$ tom smislu, nastoji se pokazati kako su suvremene upravne reforme za posljedicu imale redefiniranje kategorija javnog i privatnog u teoriji organizacije. Menadžerske su reforme uvjetovale formiranje javnog sektora, prostora „Zamućivanja“ granica javnog i privatnog. Osnovna karakteristika javnog sektora je postojanje, tzv. paradržavnih organizacija čija ,javnost“ nije uvijek neupitna. Ta je realnost za posljedicu imala i redefiniranje kategorija javnog i privatnog u teoriji organizacije. Definicija ,javne“ organizacije promijenila se i nastavlja se mijenjati usporedno s upravnim razvojem.

U okviru teorije organizacije mogu se identificirati četiri pristupa ,javnosti“ organizacije: najstariji je formalni pristup, zatim slijedi dimenzionalni koji se javlja sedamdesetih godina, najnoviji pristupi koji se bave svojstvom ,javnosti“ organizacije su normativni i integrativni.

\subsection{Formalni pristup}

Prvi su teoretičari organizacije u svojim stavovima o postojanju ključnih razlika između javnih i privatnih organizacija bili radikalno podijeljeni; bilo je moguće identificirati dva oprečna stajališta. Prema prvome, a koji se nastavlja na Fayolovu i Taylorovu tradiciju u izučavanju organizacija, ne postoji razlika između organizacija javnog i privatnog sektora. Sve zakonitosti koje vrijede za organizacije privatnog sektora, u jednakoj su mjeri valjane i za upravne organizacije. Razlikovanje organizacija na javne i privatne treba biti odbačeno kao mit, odnosno stereotip. Znanost

40 Pusić, E., Upravljanje..., cit., str. 15. 
treba biti usmjerena na istraživanje zakonitosti koje vrijede za sve organizacije i u tom se smislu inzistiralo na varijablama kao što su veličina, zadaci ili tehnologija organizacije u razumijevanju njenog ponašanja. ${ }^{41}$ Nasuprot tomu je uvjerenje kako se privatne i javne organizacije fundamentalno razlikuju. ${ }^{42}$ Javni interes razlikuje se od privatnog. Javni je sektor suočen s većim brojem vrijednosti koje bi trebao ostvariti. Organizacije javne uprave moraju voditi računa o načelima u pravilu nebitnim za privatna poduzeća, kao što su otvorenost, transparentnost, jednako postupanje, nepristranost i predvidljivost. Drugi argument koji govori u prilog različitog tretmana organizacija privatnog i javnog sektora činjenica je da su čelnici upravnih organizacija za svoj rad u konačnici odgovorni građanima. Naime, javna uprava neke države dio je šireg političko-upravnog sistema i izvršne vlasti, a čelnici ministarstava politički su imenovane osobe. ${ }^{43}$

$\mathrm{S}$ vremenom se javila potreba premošćivanja ovih oprečnih stavova s obzirom na to da su se temeljili na definiciji javnosti organizacije koja je u praksi već bila prevladana, odnosno koja nije odgovarala stvarnosti javnog sektora. I jedna i druga grupa teoretičara polazila je u definiranju javne i privatne organizacije od kategorije vlasništva nad organizacijom. Javna je ona organizacija koja je u javnom vlasništvu, bilo da se radi o tijelima državne uprave ili, pak, ustanovama i poduzećima. Iako ovaj pristup ne negira da postoje sličnosti između organizacija u privatnom $i$ onih $u$ javnom vlasništvu, temeljna je presumpcija kako je pravni status organizacije ključan za njezino razumijevanje. Javno ili privatno vlasništvo ima za djelovanje organizacije niz posljedica. Organizacije u javnom vlasništvu karakterizira, između ostaloga, veći formalizam. Formalizam se pritom odnosi na broj pravila i formalnih postupaka $\mathrm{s}$ kojima je organizacija suočena. Tako su, primjerice, Holdaway i dr. pronašli veću razinu formalizma kod kanadskih javnih sveučilišta nego što je to bio slučaj kod privatnih. ${ }^{44}$ Slične rezultate dobili su Chubb i Moe uspoređujući privatne i javne škole u SAD-u. ${ }^{45}$

Nedostatak formalnog definiranja javnosti organizacije je što ne može objasniti iznimke koje se u stvarnosti javljaju, odnosno „hibridne“ organizacije. U nekim će situacijama biti relativno lako klasificirati organizaciju s obzirom na njenog osnivača, primjerice, u sektoru obrazovanja jednostavno će biti prepoznati koje su škole ili visokoškolske ustanove javne, a koje privatne. U drugim će situacijama to biti puno teže. Primjer je poznato američko poduzeće General Motors kada je 2009. američka vlada preuzela $61 \%$ udjela u poduzeću. Iako je uprava poduzeća ostala ista, savezna

41 Christensen, T. i dr., Organization Theory and the Public Sector. Instrument, Culture and Myth, London/New York, Routledge, 2007., str. 4.

$42 \mathrm{U}$ tom je smislu kultni status stekla Sayrova izjava kako su javne i privatne organizacije slične u svim nevažnim aspektima. Dakle, različite su u svim bitnim pogledima. Sayre, W. S., Premises of Public Administration: Past and Emerging, Public Administration Review, vol. 18, 2/1958., str. 102.

43 Christensen, T. i dr., op. cit., str. 4-6.

44 Holdaway, E. i dr., Dimensions of Organizations in Complex Societies: The Educational Sector, Administrative Science Quarterley, vol. 20, 1/1975., str. 55.

45 Chubb, J., Moe, T., Politics, Markets and the Organization of Schools, American Political Science Review, vol. 82, 4/1988., str. 1080. 
regulacija branila im je slobodno raspolaganje imovinom poduzeća ${ }^{46}$ Opravdano se postavilo pitanje je li to poduzeće privatno ili javno? Kao rješenje pojavio se dimenzionalni pristup.

\subsection{Dimenzionalni pristup}

Rasprava o ,javnosti“ organizacija doživjela je novi uzlet upravo sedamdesetih i osamdesetih godina usporedno s prihvaćanjem menadžerskih reformi u zemljama Zapada. S obzirom na to da je novi upravni razvoj značio prerastanje granice javne uprave i širenje na područje javnog sektora, s pravom se postavilo pitanje, je li uopće moguće i s kojim posljedicama imputirati javni interes privatnom poduzeću? Ili suprotno, uvoditi menadžersku praksu iz privatnog sektora u upravne organizacije, primjerice, uvođenje fleksibilnijih modela plaćanja i uopće zapošljavanja državnih i javnih službenika? Pitanje o razlici javnih i privatnih organizacija u literaturi je od tada poznat i kao the publicness puzzle. ${ }^{47}$

Kritičari formalnog pristupa upozorili su kako je problem sa svođenjem razlike između javnog i privatnog na dimenziju vlasništva nad organizacijom to što se temelji na pretpostavci koju bi tek trebalo dokazati, kako javno vlasništvo organizaciju u većoj mjeri podvrgava vladinoj kontroli, a manje zakonitostima tržišta, odnosno, drugim nevladinim kontrolnim procesima. Državne organizacije (primjerice, agencije) mogu uživati znatan stupanj samostalnosti u odnosu na političku vlast, a privatna poduzeća mogu u znatnoj mjeri biti ograničena i sputana državnom regulacijom..$^{48}$ Svjesni ovog problema Wamsley i Zald u svoju su definiciju javnih organizacija uz formalni status uključili i način, odnosno izvor njihova financiranja. Za njih su javne organizacije one koje je osnovala i financirala država, privatne organizacije su one koje su u privatnom vlasništvu i istovremeno se financiraju zahvaljujući svojoj aktivnosti na tržištu ili privatnim donacijama. U slučajevima u kojima dolazi do preklapanja, privatno vlasništvo uz javno financiranje ili javno vlasništvo u kombinaciji s privatnim sredstvima, radi se o mješovitim ili hibridnim organizacijama. Tu će ulaziti poduzeća u državnom vlasništvu. Wamsley i Zald su smatrali kako je stupanj vanjske kontrole koju na organizaciju vrše političke institucije odnosno tržište, ključan za njihovo razlikovanje. Vlasništvo i izvor financiranja držali su za organizacijska svojstva koja odražavaju izvor ove kontrole..$^{49}$

Takvo definiranje javnosti organizacije koje se temelji na izvoru kontrole (autoritetu) nad organizacijom predstavljao je prekretnicu s obzirom na tradicionalni, formalni pristup. Novi pristup organizaciju promatra s aspekta teorije otvorenog

46 Rauh, J., Problems in Identifying Public and Private Organizations: A Demonstration Using a Simple Naive Bayesian Classification, Public Organization Review, vol. 15, 1/2013., str. 36.

47 Bozeman, B. i dr., The 'Publicness Puzzle' in Organization Theory: A Test of Alternative Explanations of Differences Between Public and Private Organizations, Journal of Public Administration Research and Theory, vol. 4, 2/1994., str. 197-223.

48 Perry, J., L., Rainey, H. G., The Public-Private Distinction in Organization Theory: A Critique and Research Strategy, Academy of Management Review, vol. 13, 2/1988., str. 184.

49 Wamsley, G. L., Zald, M. N., The Political Economy of Public Organizations, Public Administration Review, vol. 33, 1/1973., str. 64 
sistema. To znači da prihvaća kako organizacije djeluju u određenoj okolini i da njezine aktivnosti uvelike ovise o tom kontekstu. Ako želimo razumjeti javnost organizacije i njezino ponašanje nužno je krenuti od okoline u kojoj je organizacija situirana i u kojoj djeluje. Kvalifikacija organizacije kao javne, privatne ili mješovite, ovisi o vrsti i stupnju „društvene kontrole“ kojoj je podvrgnuta svaka organizacija. ${ }^{50}$

Pristup je dalje razradio Bozeman koji u svojoj knjizi „Sve su organizacije javne“" (All Organizations Are Public), iznosi stav kako je javnost, kao karakteristika svake organizacije, dimenzionalna. Sve su organizacije više ili manje javne jer su podložne, bar u nekoj mjeri, vladinoj, odnosno političkoj, kontroli i utjecaju. ${ }^{51}$ Pristup je dimenzionalan jer se u kvalifikacije neke organizacije kao privatne ili javne, osim vlasništva razmatra i način na koji je organizacija financirana kao i postoji li i kakva kontrola nad djelovanjem organizacije. Organizacija može biti više ili manje javna po svakoj od tri dimenzija javnosti: vlasništvu, financiranju i kontroli. Prema Bozemanovu modelu, malo koja organizacija je ili u potpunosti privatna ili u potpunosti javna. Ponašanje organizacije uvijek je rezultat postojanja mješavine javnog i privatnog autoriteta koji ima utjecaj na aktivnosti organizacije. Svojstvo javnosti organizacije neovisno je njezinom formalnom, pravnom statusu. Moguće je zamisliti kako su neke državne organizacije više javne od drugih, kao i da su neka privatna poduzeća više privatna od drugih. Bozeman je, u tom smislu, u kontekstu istraživanja organizacija u zrakoplovnoj industriji, identificirao dimenzije javnosti organizacija koje su, s perspektive vlasništva, bile u potpunosti privatne..$^{52}$

Ideja o „dimenzinalnoj“ javnosti temelji se na pitanju o izvoru kontrole nad organizacijom ili izvoru autoriteta. Kako bi razlikovao javne od privatnih organizacija, Bozeman promatra stupanj utjecaja koji na neku organizaciju ima politički ili ekonomski autoritet. Što veći utjecaj na organizaciju ima politički autoritet ona je u većoj mjeri javna, a ako njezin opstanak ovisi o tržištu, u većoj je mjeri privatna. Politički autoritet počiva na pretpostavci da se svaka organizacija može prisiliti na ponašanje koje odgovara političkoj zajednici. Ekonomski autoritet presumira da se organizacije ponašaju na način koji njihovim vlasnicima (dioničarima) osigurava najveću dobit. ${ }^{53}$ Kao pokazatelji javnosti organizacija u kasnijim istraživanjima uzimao se udio sredstava koje organizacija prima od države, frekvencija komunikacije vlade i organizacije, važnost države za rast i opstanak organizacije. ${ }^{54}$ Primjerice, prema

50 Moulton, S., Putting Together the Publicness Puzzle: A Framework for Realized Publicness, Public Administration Review, vol. 69, 5/2009., str. 890.

51 Bozeman, B., All Organizations Are Public: Comparing Public and Private Organizations, Washington, Beard Books, 1987., str. 82.

52 Bozeman, B., Dimensions of 'Publicness': An Approach to Public Organization Theory, u Bozeman, B., Straussman, J. (ur.) New Directions in Public Administration, Monterey, Brooks/ Cole, 1984., str. 58.

53 Miller, S., Moulton, S., The Publicness of Organizations and Policy Environments on Public Service Outcomes: A Multi-Level Analysis of Substance Abuse Treatment Services, Journal of Public Administration Research and Theory, vol. 24, 3/2014., str. 555.

54 Vidi: Bozeman, B., Bretschneider, S., The 'Publicness Puzzle' in Organization Theory: A Test of Alternative Explanations of Differences Between Public and Private Organizations, Journal of Public Administration Research and Theory, vol. 4, 2/1994.; Bozeman, B. i dr., Red Tape and Task Delays in Public and Private Organizations, Administration \& Society, vol. 24, 3/1992. 
dimenzionalnom pristupu, privatno poduzeće koje se bavi proizvodnjom oružja i njegov je primarni kupac država bila bi organizacija s visokim stupnjem javnosti s obzirom na to da većinu prihoda ostvaraju na temelju ugovora s državom, što znači da u konačnici opstaje zahvaljujući državnom financiranju. ${ }^{55}$

\subsection{Normativni pristup}

Normativni pristup dovodi $\mathrm{u}$ vezu javnost organizacije i određenu grupu vrijednosti u javnoj upravi, odnosno javni interes. ${ }^{56}$ Javnost se definira ovisno o tomu koliko je organizacija privržena javnim vrijednostima, odnosno doprinosi njihovom ostvarenju.

Antonsen i Jørgensen istraživali su javnost danskih upravnih organizacija definirajući javnost kao opredijeljenost i usmjerenost na vrijednosti tradicionalno vezanih uz javni sektor, kao što su pravičan postupak, odgovornost i socijalna osjetljivost, za razliku od ekonomskih vrijednosti koje su primarne u privatnom sektoru. ${ }^{57}$ Istraživali su stupanj javnosti formalno javnih organizacija, kao što su javna (državna) sveučilišta i druge javne (državne) visokoškolske institucije, kulturne ustanove (nacionalno kazalište, galerija i knjižnica), regulatorne agencije, znanstvene $\mathrm{i}$ istraživačke institucije te pružatelji mrežnih odnosno infrastrukturnih usluga (nacionale željeznice, poštanska služba). Bez obzira na razlike u poslovima koje obavljaju, svim je organizacijama bila zajednička činjenica da su, prema formalnom pravnom kriteriju, javne, te ih istodobno financira država i za svoj su rad odgovorne nadležnom ministarstvu. Rezultati njihova istraživanja pokazali su bitne razlike među njima u smislu ,privrženosti“ javnim vrijednostima. Neke su organizacije pokazale snažnu usmjerenost prema vrijednostima tradicionalno prisutnim u privatnom sektoru. Primjerice, neka su sveučilišta prema rezultatima istraživanja, ušla u grupu upravnih organizacija s visokim stupnjem javnosti, druga u skupinu koju karakterizira nizak stupanj javnosti.

Normativni je pristup, za razliku od formalnog i dimenzionalnog koji su deskriptivni, preskriptivan. Autori inzistiraju na zaštiti i promicanju javnih vrijednosti u kontekstu javnog sektora neovisno o formalnom statusu organizacije, odnosno je li organizacija koja obavlja javnu službu državna, ugovaratelj ili privatno poduzeće. ${ }^{58}$

55 Perry, J. L., Rainey, H. G., op. cit., str. 190.

56 Vidi: Antonsen, M., Jørgensen, T. B., The 'Publicness' of Public Organizations, Public Administration, vol. 75, 2/1997.; van der Wal, Z., Huberts, L., Value Solidity in Government and Business, American Review of Public Administration, vol. 38, 3/2008.; Bozeman, B., Public Values and Public Interest: Counterbalancing Economic Individualism, Washington DC, Georgetown University Press, 2007.; Bozeman, B., Sarewitz, D., Public Values and Public Failure in U.S. Science Policy, Science and Public Policy, vol. 32, 2/2005.; Haque, M. S., The Diminishing Publicness of Public Service Under the Current Mode of Governance, Public Administration Review, vol. 61, 1/2001.; Jørgensen, T. B., Bozeman, B., Public Values: An Inventory, Administration \& Society, vol. 39, 3/2007.

57 Antonsen, M., Jørgensen, T. B., op. cit., str. 340.

58 U domaćoj literaturi Koprić se bavio vrijednosnim usmjerenjem organizacija, iako ga nije dovodio u vezu sa svojstvom javnosti organizacije. On razlikuje šest tipova organizacijske kulture (legalističku, participativnu, poduzetničku, birokratsku, autoritarnu, upravljačku), 


\subsection{Integrativni pristup}

Najnoviji pristup problemu javnosti organizacije nastoji integrirati dimenzionalni i normativni pristup. Integrativni pristup, kao i dimenzionalni, polazi od toga kako vlasništvo nad organizacijom nije nužan pokazatelj njenog ponašanja. S druge strane, upozorava kako dimenzionalni pristup, iako možda i daje primjereni opis organizacija koje pronalazimo u javnom sektoru, ne može predvidjeti output organizacije, a onda ni javnog sektora u cjelini. A ključno je pitanje kako osigurati da javni sektor djeluje u javnom interesu? Odnosno, umjesto pitanja „koja obilježja kvalificiraju organizaciju kao javnu“, integrativni pristup postavlja pitanje „koje okolnosti ili faktori osiguravaju postupanje organizacije u skladu s javnim interesom?"59 Kako bi ponudio odgovor na ovo pitanje, poseže za tekovinama normativnog pristupa spajajući ga s teorijom neoinstitucionalizma.

Prema integrativnom pristupu, organizacija je javna u onoj mjeri u kojoj uistinu ostvaruje (realizira) javne vrijednosti/javni interes. U tom smislu Moulton uvodi koncept „realizirane javnosti“ (engl. realized publicness). Institucionalna okolina organizacije, odnosno formalno i neformalno institucionalizirane vrijednosti bitno pridonose realizaciji javnosti organizacije. Pritom vrijednosti nisu samo set normi čiji je izvor država, a kojih se organizacija mora pridržavati u svome postupanju kao kod normativnog pristupa. Vrijednosti su institucionalizirane i neformalno kroz različite asocijacije (primjerice, građani i njihove udruge, lokalna zajednica) i u organizacijskoj kulturi. Ove neformalne institucije čine okolinu u koju je organizacija „uklopljena“ i uvelike doprinose ili otežavaju ostvarenje javnog interesa. Stoga, na organizacije i rezultate koje one ostvaruju moguće je utjecati manipulirajući okolinom organizacije. ${ }^{60}$

Integrativni pristup istraživanju javnosti organizacije sastoji se od tri koraka. Najprije je potrebno identificirati željene ishode, što je u javnom interesu na nekom policy području; zatim odrediti indikator ili mjeru „realizirane javnosti“ te je potrebno identificirati čimbenike koji doprinose ili otežavaju „realizaciju javnosti“ ${ }^{61} .{ }^{61}$ Feeney i Welch, na tom tragu, istraživali su čimbenike koji uvjetuju javnost američkih sveučilišta. Kao javni interes na području znanosti i visokog obrazovanja identificirali su, između ostaloga, stvaranje znanja (engl. knowledge creation) i podučavanje. Za indikatore „realizirane javnosti“ uzeli su broj publikacija i patenata na nekom sveučilištu te broj studenata, odnosno prestiž koji uživa sveučilište. Model je pokazao kako su čimbenici koji utječu na realizaciju javnosti sveučilišta trostruki: regulativni (savezno zakonodavstvo i propisi država), asocijativni (formalne i neformalne organizacije čiji su članovi sveučilišta ili pojedini djelatnici sveučilišta) i kulturnokognitivni (organizacijska kultura i vrijednosti članova akademske zajednice). Pa su tako, primjerice, ona sveučilišta čiji su nastavnici i djelatnici, u provedenom

ovisno o praktičnoj orijentaciji službenika koji u njima rade i vrijednostima koje prevladavaju u organizaciji (pravne, političke ili ekonomske). Koprić, I., Struktura..., cit., str. 281.

59 Moulton, S., op. cit., str. 889.

60 Ibid., str. 889.

61 Ibid., str. 897. 
istraživanju, bili uglavnom kozmopolitski usmjereni i njegovali organizacijsku kulturu koja podržava različitost i toleranciju, bila uspješnija u podučavanju. ${ }^{62}$

Moulton je u istraživanju javnosti financijskih institucija također pronašla kako organizacijska kultura i asocijativna okolina organizacija itekako mogu potkopati ili unaprijediti djelovanje državne regulacije (zakona). Naime, kako bi se osiguralo djelovanje u javnom interesu, ostvarenje socijalne sigurnosti, američki je zakonodavac (Home Mortgage Disclosure Act i Community Reinvestment Act) ograničio djelovanje banaka i drugih financijskih institucija davatelja hipotekarnih kredita na način da ih je najprije obvezao na strogu transparentnost u poslovanju, a zatim nametnuo obvezu ,posluživanja“ i stanovništva s nižim prihodima, odnosno, osiguranja pristupa hipotekama i siromašnijim građanima. Moluton je pronašla kako su socijalne vrijednosti (stambena sigurnost) više ostvarene u onim zajednicama gdje je zakonodavstvo bilo podržano odgovarajućom organizacijskom kulturom i asocijativnom okolinom. Više je bilo vlasnika stanova i stambenih prostora u onim područjima u kojima su stanovnici bili bolje organizirani, bilo u vidu neprofitnih organizacija ili drugih udruga građana, kao i u onim područjima gdje su izostale financijske institucije s ,predatorskom“ organizacijskom kulturom, a prisutne su bile one koje su više dijelile interese lokalne zajednice. ${ }^{63}$

Integrativni pristup temelji se na neoinstitucionalnoj teoriji. Na policy ishod, djelovanje u javnom interesu, kako god ono bilo definirano, utječu regulatorne, asocijativne i kulturno-kognitivne institucije. Najčešće pod regulatornim institucijama misli se na državu, odnosno tijela državne i javne uprave s regulacijskim ovlastima. Oni će se, kako bi osigurali željeno ponašanje, poslužiti sankcijom. Asocijativne institucije predstavljaju različite organizacije i udruge građana u najširem smislu riječi. Kulturno-kognitivne institucije temelje se na percepciji o prirodi društvene stvarnosti. Može se raditi, primjerice, o stavovima koji dijele zaposleni u nekoj organizaciji. ${ }^{64}$ Institucije su sposobne utjecati na aktere, organizacije u pitanju, i oblikovati njihovo ponašanje. One predstavljaju ,pravila igre u društvu“ ${ }^{65}$

Integrativni pristup doprinosi diskusiji o zamagljivanju granica između javne $\mathrm{i}$ privatne sfere argumentirajući kako ostvarenje javnog interesa na nekom području, bilo na području zdravstva, školstva ili drugog resora, ovisi ne toliko o „mješavini““ različitih tipova organizacija (javnih i privatnih) koliko o „mješavini“ institucija: regulativnih, asocijativnih i kulturno-kognitivnih. Jer, institucije su te koje mogu utjecati na aktere i oblikovati njihovo ponašanje.

\section{ZAKLJUČAK}

Reforme često imaju neočekivane posljedice. Iako su prvotno bile zamišljene i usmjerene na smanjenje javne uprave i širenje prostora djelovanja tržišta, menadžerske

62 Feeney, M. K., Welch, E. W., Realized Publicness at Public and Private Research Universities, Public Administration Review, vol. 72; 2/2012., str. 280-281.

63 Moulton, op. cit., str. 895-896.

64 Ibid., str. 892-894.

65 North, D. C., Institutions, Institutional Change and Economic Performance, New York, Cambridge University Press, 1990., str. 3. 
reforme osamdesetih godina 20. stoljeća za posljedicu su imale formiranje javnog sektora, prostora zajedničkog djelovanja javnog i privatnog. Cilj je ovoga rada doprinijeti raspravi o implikacijama menadžerskog vala reformi javne uprave na način da uputi na teorijsku raspravu o razlici između javnih i privatnih organizacija. Dakle, $\mathrm{u}$ radu se dovode u vezu posljedice suvremenih upravnih reformi, oblikovanje javnog sektora, $\mathrm{s}$ teorijskom raspravom o razlici između javnih i privatnih organizacija pokazujući kako je, usporedno s upravnim razvojem i porastom složenosti upravnog sistema, i definicija ,javne“ organizacije postajala sve složenija.

Osnovno su obilježje javnog sektora organizacije za koje prima facie nije sasvim jasno u koju sferu društva ulaze: država, tržište ili civilno društvo. Pusić takve organizacije naziva ,paradržavnim“. Iako su načelno vezane javnim vrijednostima, odnosno javnim interesom, istodobno ili uživaju visoki stupanj samostalnosti od političke vlasti (primjerice, agencije) ili djeluju vodeći se i tržišnim principima (javna poduzeća, hibridna poduzeća i sl.). Neposredno s ovim promjenama mijenja se i odgovor na pitanje što je to javno, a što privatno, odnosno što je bit ,javne“ organizacije.

Sve do zadnje četvrtine 20. stoljeća razlikovanje između javnog i privatnog $\mathrm{u}$ teoriji organizacije bilo je relativno jednostavno. Radilo se o formalnom pristupu koji je organizacije razlikovao temeljem pravne kategorije vlasništva. Javne su one organizacije koje su u javnom vlasništvu, što je uključivalo organizacije državne uprave, ali i javna poduzeća i javne ustanove. Privatne su sve ostale, odnosno one čiji „vlasnik“ nije država. U posljednjoj četvrtini 20. stoljeća javna uprava država Zapada prolazi kroz važne reforme. Na djelu su reforme utemeljene na doktrini NJM-a. Prema tom pristupu, upravljanje u državnoj, odnosno javnoj upravi nije posebne naravi, te se stoga treba inspirirati tržišnim metodama i načinom upravljanja. Kao nositelji javnih službi sve se češće javljaju privatna poduzeća ili se privatne subjekte na nove načine angažira kao nositelje javnih poslova (primjerice, javno-privatno partnerstvo, outsourcing i sl.).

Neposredno s ovim promjenama, rasprava o razlici između javnih i privatnih organizacija doživljava preokret. U istraživanjima najprije Wamsleya i Zalda te kasnije Bozemana razvijene su rafiniranije metode razlikovanja javnih i privatnih organizacija. Ovaj novi pristup u literaturi se naziva dimenzionalnim ili još deskriptivnim. Sve su organizacije više ili manje javne jer su podložne, bar u nekoj mjeri, vladinoj, odnosno političkoj, kontroli i utjecaju. Svojstvo javnosti organizacije neovisno je o njezinu formalno pravnom statusu. Pristup je dimenzionalan jer organizacija može biti više ili manje javna po svakoj od tri dimenzija javnosti: vlasništvu, financiranju i kontroli. Prema Bozemanovu modelu, malo koja organizacija je ili u potpunosti privatna ili u potpunosti javna. Ponašanje organizacije uvijek je rezultat postojanja mješavine javnog i privatnog autoriteta koji utječe na aktivnosti organizacije.

Trenutačno su aktualna dva smjera u istraživanju ,javnosti“ organizacija. Prvi, normativni pristup smatra kako je svojstvo ,javnosti“ organizacije povezano s njezinim vrijednosnim usmjerenjem. Ona organizacija koja ispred ekonomskih, cijeni političke, pravne i socijalne vrijednosti u većoj je mjeri ,javna“. Drugi smjer u istraživanju ,javnosti“ organizacija, integrativni pristup nastoji povezati dimenzionalni pristup s 
normativnim pristupom na način da našu pažnju usmjerava prema institucionalnoj okolini organizacije. Javna je ona organizacija koja uistinu ostvaruje javne vrijednosti, odnosno javni interes. A ostvarenje javnog interesa na nekom policy području bitno će ovisiti o podršci neformalnih institucija, asocijativnih i kulturno-kognitivnih. Hoće li organizacija uspjeti „,realizirati svoju javnost“, doprinijeti ostvarenju javnog interesa ili ne, ovisi o njezinoj institucionalnoj okolini. Moulton je pokazala kako je pod određenim uvjetima moguće očekivati postupanje u javnom interesu/ostvarenje javnih vrijednosti od formalno privatnih organizacija. Takav će ishod biti moguć u onim situacijama kada je državna regulacija poduprta odgovarajućom neformalnom okolinom poput mreže aktera civilnog društva i odgovarajuće organizacijske kulture.

\section{LITERATURA}

1. Antonsen, Marianne, Jørgensen, Torben Beck, The 'Publicness' of Public Organizations, Public Administration, vol. 75, 2/1997., str. 337-357.

2. Bertalanffy, Ludwig von, General System Theory - Foundations, Development, Applications, Harmondsworth (UK), Penguin Books, 1973.

3. Blažević, Robert, Upravna znanost, Rijeka, Pravni fakultet Sveučilišta u Rijeci, 2016.

4. Bozeman, Barry, Dimensions of 'Publicness': An Approach to Public Organization Theory, u: Bozeman, Barry, Straussman, Jeffrey (ur.) New Directions in Public Administration, Monterey (SAD), Brooks/ Cole, 1984., str. 46-62.

5. Bozeman, Barry, All Organizations are Public, San Francisco (SAD), Jossey-Bass, 1987.

6. Bozeman, Barry, Public Values and Public Interest: Counterbalancing Economic Individualism, Washington DC (SAD), Georgetown University Press, 2007.

7. Bozeman, Barry, Sarewitz, Daniel, Public Values and Public Failure in U.S. Science Policy, Science and Public Policy, vol. 32, 2/2005., str. 119-136.

8. Bozeman, Barry, Bretschneider, Stuart, The 'Publicness Puzzle' in Organization Theory: A Test of Alternative Explanations of Differences Between Public and Private Organizations, Journal of Public Administration Research and Theory, vol. 4, 2/1994., str. 197-223.

9. Bozeman, Barry, Reed, Pamela N., Scott, Patrick, Red Tape and Task Delays in Public and Private Organizations, Administration \& Society, vol. 24, 3/1992., str. 290-322.

10. Christensen, Tom, Lægreid, Per, Roness, Paul G., Røvik, Kjell Arne, Organization Theory and the Public Sector. Instrument, Culture and Myth, London/New York, Routledge, 2007.

11. Chubb, John E., Moe, Terry M., Politics, Markets and the Organization of Schools, American Political Science Review, vol. 82, 4/1988., str. 1065-1087.

12. Egeberg, Morten, How Bureaucratic Structure Matters: An Organizational Perspective, u: Peters, Guy B., Pierre, Jon, (ur.) The SAGE Handbook of Public Administration, Thousand Oaks/London/New Delhi, SAGE Publications, 2012., str. 143-154.

13. Feeney, Mary K., Welch, Eric W., Realized Publicness at Public and Private Research Universities, Public Administration Review, vol. 72, 2/2012., str. 272-284.

14. Haque, M. Shamsul, The diminishing publicness of public service under the current mode of governance, Public Administration Review, vol. 61, 1/2001., str. 65-82.

15. Hatch, Mary Jo, Cunliffe, Ann L., Organization Theory: Modern, Symbolic, and Postmodern Perspectives, 3. izd., Oxford, Oxford University Press, 2013.

16. Holdaway, Edward A., Newberry, John F., Hickson, David J., Heron, Peter, Dimensions of Organizations in Complex Societies: The Educational Sector, Administrative Science Quarterley, vol. 20, 1/1975., str. 37-58. 
17. Jordana, Jacint, Levi-Faur, David, The Politics of Regulation in the Age of Governance, $\mathrm{u}$ : Jordana, Jacint, Levi-Faur, David, (ur.) The Politics of Regulation. Institutions and Regulatory Reforms for the Age of Governance, Cheltenham (UK), Edward Elgar, 2004., str. 1-30.

18. Jørgensen, Torben Beck, Bozeman, Barry, Public values: An inventory, Administration \& Society, vol. 39, 3/2007., str. 354-381.

19. Koprić, Ivan, Građani i uprava, u: Koprić, Ivan (ur.) Javna uprava. Nastavni materijali, Zagreb, Društveno veleučilište u Zagrebu/Pravni fakultet u Zagrebu, 2006., str. 19-23.

20. Koprić, Ivan, Kriza socijalne države i menadžerske reforme javne uprave, u: Koprić, I. (ur.) Javna uprava. Nastavni materijali, Zagreb, Društveno veleučilište u Zagrebu/Pravni fakultet u Zagrebu, 2006., str. 137-158.

21. Koprić, Ivan, Marčetić, Gordana, Musa, Anamarija, Đulabić, Vedran, Lalić Novak, Goranka, Upravna znanost. Javna uprava u suvremenom europskom kontekstu, Zagreb, Pravni fakultet Sveučilišta u Zagrebu, 2014.

22. Koprić, Ivan, Struktura i komuniciranje u upravnim organizacijama, Zagreb, Pravni fakultet Sveučilišta u Zagrebu, 1999.

23. Kuhlmann, Sabine, Reforming Local Public Services: Trends and Effects in Germany and France, Public Management Review, vol. 10, 5/2008., str. 573-596.

24. Lawrence, Paul R., Lorsch, Jay W., Visoko uspješne organizacije u tri okoline, u: Pusić, Eugen (ur.) Upravna znanost, Zagreb, Naklada Naprijed, 1995., str. 239-261.

25. Marčetić, Gordana, Upravljanje ljudskim potencijalima u javnoj upravi, Zagreb, Društveno veleučilište u Zagrebu, 2007.

26. March, James G., Olsen, Johan P., The New Institutionalism: Organizational Factors in Political Life, American Political Science Review, vol. 78, 3/1983., str. 734-749.

27. Meyer, J. W., Rowan, B., Institutionalized Organizations: Formal Structure as Myth and Ceremony, u: Powell, W. W., DiMaggio, P. J. (ur.) The New Institutionalism in Organizational Analysis, Chicago/London, University of Chicago Press, 1991., str. 41-62.

28. Mikić, M. i dr. (ur.), Ekonomski leksikon, 2. izd., Zagreb, Leksikografski zavod Miroslav Krleža/Masmedia, 2011.

29. Miller, Susan, Moulton, Stephanie, The Publicness of Organizations and Policy Environments on Public Service Outcomes: A Multi-Level Analysis of Substance Abuse Treatment Services, Journal of Public Administration Research and Theory, vol. 24, 3/2014., str. 553-589.

30. Moran, Michael, Not Steering but Drowning: Policy Catastrophes and the Regulatory State, The Political Science Quarterly, vol. 72, 4/2001., str. 414-427.

31. Morgan, Gareth, Images of Organization, Thousand Oaks/London/New Delhi, SAGE Publications, 1997.

32. Moulton, Stephanie, Putting Together the Publicness Puzzle: A Framework for Realized Publicness, Public Administration Review, vol. 69, 5/2009., str. 889-900.

33. North, Douglass C., Institutions, Institutional Change and Economic Performance, New York, Cambridge University Press, 1990.

34. Perko-Šeparović, Inge, Izazovi javnog menadžmenta. Dileme javne uprave, Zagreb, Golden marketing/Tehnička knjiga, 2006.

35. Perko-Šeparović, Inge, Teorije orgnizacije, Zagreb, Školska knjiga, 1975.

36. Perry, James L., Rainey, Hal G., The Public-Private Distinction in Organization Theory : A Critique and Research Strategy, Academy of Management Review, vol. 13, 2/1988., str. 182-201.

37. Pollit, Christopher, Bouckaert, Geert, Public Management Reform: A Comparative Analysis - New Public Management, Governance, and the Neo-Weberian State, Oxford, Oxford University Press, 2011.

38. Pusić, Eugen, Modernizacija uprave - obrati i trajanja, u: Pusić, Eugen (ur.) Upravna znanost, Zagreb, Naklada Naprijed, 1995., str. 7-101. 
39. Pusić, Eugen, Upravljanje u suvremenoj državi, Zagreb, Suvremena javna uprava, 2002.

40. Rauh, Jonathan, Problems in Identifying Public and Private Organizations: A Demonstration Using a Simple Naive Bayesian Classification, Public Organization Review, vol. 15, 1/2013., str. 33-47.

41. Sayre, Wallace S., Premises of Public Administration: Past and Emerging, Public Administration Review, vol. 18, 2/1985., str. 102-105.

42. Shafritz, Jay M., Ott, J. Steven, Jang, Yong Suk, Classics of Organization Theory, 6. izd., Belmont (SAD), Thomson Wadsworth, 2005.

43. Van der Wal, Zeger, Huberts, Leo, Value solidity in government and business, American Review of Public Administration, vol. 38, 3/2008., str. 264-285.

44. Wamsley, Gary L., Zald, Mayer N., The political economy of public organizations, Public Administration Review, vol. 33, 1/1973., str. 62-73.

45. Wollmann, Hellmut, Marcou, Gérard, From Public Sector-based to Privatized Service Provision. Is the Pendulum Swinging Back Again? Comparative Summary, u: Wollmann, Hellmut, Marcou, Gérard (ur.) The Provision of Public Services in Europe, Between State, Local Government and Market, Cheltenham/Northampton, Edward Elgar, 2010., str. 240260. 


\section{Mariza Menger*}

Summary

\section{DEVELOPMENT OF THE CONCEPT OF ORGANIZATIONAL PUBLICNESS IN ORGANIZATIONAL THEORY}

This paper is concerned with the issue of public - private divide within the theory of organization. The main argument is that with administrative development and change, the definition of public, as opposed to private organization, also changes. Current state of public administration is characterized by the blurring of boundaries between public and private sectors. Due to such development the approach to public - private distinction had change. Traditionally, public organizations were identified as public on the basis of formal, legal criteria of ownership: organizations in the property of the state were considered public, and those in the private ownership, private. Modern public administration challenges this formula. Thus, it is possible to distinguish four approaches in the conceptualization of publicness of an organization: the oldest, formal approach, dimensional, normative and integrative approach.

Keywords: theory of organization, public services, public administration, public sector, new public management.

Zussamenfassung

\section{DIE ENTWICKLUNG DER AUFFASSUNG ,DER ÖFFENTLICHKEIT" VON ORGANISATIONEN IN DER ORGANISATIONSTHEORIE}

Die Arbeit bespricht die Konzeptualisierung der Begriffe „,des Öffentlichen“ und „des Privaten“ in der Organisationstheorie. Ziel der Arbeit ist es, darauf hinzuweisen, dass sich mit der Entwicklung der Verwaltung auch die Ansätze zum Unterscheiden zwischen öffentlicher und privater Organisation änderten. Die Verwaltung selbst entwickelt sich in Richtung der immer größer Annäherung des öffentlichen und privaten Sektors. Diese Entwicklung führte auch zur Neudefinierung der öffentlichen und privaten Organisationen. Die traditionell als öffentlich bezeichneten Organisationen wurden als öffentlich und die privaten als privat definiert, und zwar, nach formellem Eigentumskriterium: die im Eigentum des Staates stehenden Organisationen wurden

66 Mariza Menger, Ph. D., Teaching Assistant, University of Rijeka, Faculty of Law; mmenger@ pravri.hr. 
als öffentlich und die im Eigentum einer Privatperson stehende Organisationen als privat angesehen. Die moderne Verwaltungsentwicklung stellte diese Formel in Frage, was zur Folge hat, dass man heute vier Ansätze zur Definierung der „Öffentlichkeit“ einer Organisation feststellen kann: der formale und gleichzeitig der älteste, der dimensionale, der normative und der integrative Ansatz.

Schlüsselwörter: Organisationstheorie, öffentliche Dienste, öffentliche Verwaltung, öffentlicher Sektor, neues öffentliches Management.

Riassunto

\section{LO SVILUPPO DELLA CONCEZIONE DI „PUBBLICITA“ DELLE ORGANIZAZZIONI NELLA TEORIA ORGANIZZATIVA}

Nel lavoro si analizza come nel contesto della teoria organizzativa vengano concettualizzate le nozioni di pubblico e privato. Lo scopo del lavoro è di dimostrare come mediante l'evoluzione amministrativa cambino anche gli approcci alla distinzione tra organizzazione pubblica e privata. L'amministrazione si sviluppa nella direzione di un sempre maggiore avvicinamento del settore pubblico e di quello privato. Tale sviluppo ha condizionato anche la rideterminazione delle nozioni dell'organizzazione pubblica e privata. Tradizionalmente le organizzazioni pubbliche erano definite come pubbliche; mentre quelle private, come private in base al criterio giuridico formale della proprietà: le organizzazioni di proprietà dello Stato si consideravano pubbliche, mentre quelle di proprietà di un soggetto privato erano ritenute private. Lo sviluppo contemporaneo dell'amministrazione ha posto in questione tale formula; perciò oggi è possibile identificare quattro approcci nella definizione del carattere "pubblico" dell'organizzazione: il più datato, quello formale, quello dimensionale, quello normativo ed, infine, quello integrativo.

Parole chiave: teoria organizzativa, enti pubblici, settore pubblico, nuovo management pubblico. 
